\title{
7. Ambrogio Lorenzetti, Niccolò Machiavelli, Thomas More: on virtues, realism and utopian thinking in public administration
}

\section{INTRODUCTION}

In this chapter we present the masterpieces of three authors - Ambrogio Lorenzetti (1290-1348), Niccolò Machiavelli (1469-1527), Thomas More (1478-1535) - as entry point to discuss three themes of major significance for PA: the role of virtues (of governors and citizens alike) in public governance, the meaning of realism (about power, about the human nature) in politics and PA, and the significance and potential of utopian thinking for PA.

Why these authors, and what are their enduring messages? The selection of thinkers is a very subjective choice by the author of this book, although not a casual one. Continuing our journey through philosophical thinking and PA through the study of these works may enable us to touch on three key, yet profoundly different, perspectives that continue to shed light on politics at large and PA in particular, even if five centuries and more separate us from the time when they were wrought out.

Starting from utopian thinking, scholars of public administration may probably associate the word and be more familiar with the notion of ideal-type, as minted by Weber (1978/1922). Ideal-types (to which we return later in the chapter) are pure forms within the world; More's utopia is a whole world 'other'. However, its otherness does not prevent, but rather enables the critique of this world and as such becomes a tool for a constructive critique, a means capable of driving behaviours towards perfection, or at least improvement, in this world. Teleological thinking may be a source of betterment: this is one key message conveyed by the masterpiece Utopia written by Thomas More and published first in Leuven, Belgium, in 1516.

By contrast, Machiavelli's masterpiece, The Prince, is about this earthly world, where power and violence are upfront - irrespective of any moral judgement we may formulate. Lorenzetti's Allegory and Effects of Good and Bad Government (a painting rather than a book in this case) is about this world, 
albeit a world in which the things as they are and the things as they ought to be are intimately connected: Lorenzetti's masterpiece is about the two destinies of this world when, respectively, the exercise of virtues is upfront or it is the dominance of vices to take roots in public governance; the former is a destiny of 'good government' and its effects on the fulfilment of the lives of its inhabitants; the latter is a story of bad government and its detrimental effects.

In this chapter we first ponder on Lorenzetti's masterpiece and its enduring teachings about the function that virtues and virtuous behaviour perform. We then turn to the 'realism' taught us - in quite crude, disenchanted terms - by Machiavelli. Finally, we mull over the meaning and possible usages of utopias for contemporary PA. The final part of the chapter discusses the insights from these works in light of concepts and notions to which the contemporary PA discourse is more accustomed, like that of ideal-type (a notion first worked out by Max Weber).

There are two preliminary important caveats for the reader, before plunging into works that date back centuries from now. The first caveat is that the notion of the separation between politics and administration, the (highly contested) Wilsonian notion of the distinction between a political sphere and the sphere of administration, and the conception of the legal-rational bureaucracy as the most rational form of political domination of Weberian ascendant (nicely summed up and discussed, for example, by Rosser, 2018), are late 19th and 20 th century conceptions that are utterly absent from the horizon of the works of the three selected authors. Politics and administration are totally intermingled in these works (but maybe this is also the case nowadays?), and the reader is asked to adjust her/his lenses to accommodate this perspective. As a second caveat, the reader should be alerted to the fact that rather than focusing on the huge influence these authors have wielded over subsequent (successive) philosophers, philosophies, the social sciences and social practices (a daunting task undertaken by many scholars whose works fill the libraries), this chapter aims at providing a journey 'back to the source', to the original writing (or painting) of these fascinating thinkers. For reasons of brevity we do not delve at any length into their time and historical-political context (there are books for this: see Ryan, 2012); instead, we focus on their most famous work, their masterpiece. And eventually we will rediscover the continued significance of the messages contained in these masterpieces for contemporary PA.

\section{AMBROGIO LORENZETTI, THE GOOD GOVERNMENT AND THE ROLE OF VIRTUES FOR PUBLIC GOVERNANCE}

We start from the set of murals painted by Ambrogio Lorenzetti in the Hall of the Nine Governors (the 'City Hall') of the Italian city of Siena between 
1338 and 1339. It is the first piece in the history of Italian art to have a civic theme. Lorenzetti was the most famous painter active at the time in the then self-governing republic of Siena. He was highly trained in philosophy (Argan, 1969 , p. 34) and was intimately acquainted with the Aristotelian-Thomistic philosophy and political philosophy (see Chapter 2), which in manifold respects his masterpiece represents through artistic means. The work is a series of frescoes - very well conserved thanks to restoration works in the final part of the 20th century - entitled Allegory and Effects of Good and Bad Government (we will refer to it in short as The Good Government in the remainder when generally referring to the entirety of the four frescoes). The paintings occupy three of the four walls of the town hall, whilst sunlight is let into the room through the fourth wall.

The first of the four paintings is the Allegory of Good Government (see Figure 7.1). Some translate this to 'Good Governance' because the Italian (or the Latin) language does not provide for a distinction like the one the English language enables between 'government' and 'governance'. We prefer the translation 'government' here, for reasons discussed in this section, but acknowledge that both carry explanatory value. (Ongaro and van Thiel, with the invaluable aid of over a dozen colleagues, have recently conducted an analysis on the 'words of public governance and management' and the ways in which certain key English words are utilised in the national PA discourses in various European languages; Ongaro and van Thiel, 2018a.) The other painting is entitled and represents the Effects of Good Government in the City and the Countryside: it is a very large painting - ca. 14 metres - about equally split into the two parts of the effects of good government in the city and the countryside respectively; the last fresco is the Allegory of Bad Government (allegory and effects on the city and the countryside). The Allegory of Good Government is dominated by virtues, on top of which are the theological virtues (those that are made possible by the Faith in Christ) and then the cardinal (or 'human') virtues, placed alongside justice and the symbol of the Municipality (in Italian language translated as Comune, a word whose root is 'common' or 'community'), whilst at the bottom are represented the army and the citizens: the people of the Republic of Siena in times of war and peace. 'Divine Sapience' is at the apex and 'Justice' stretched towards it, as if it were straining to draw from its source. Concord stems from justice in the form of ropes joined together by angels and passed to the first citizen. Various virtues are represented throughout. A peaceful and thriving city life is represented in the Effects of Good Government in the City, and a prosperous and secure countryside is depicted in the Effects of Good Government in the Countryside. Finally, the Allegory of Bad Government and the Effects of Bad Government on the City and Countryside are depicted one next to the other, forming the fourth main fresco. The representation of vices dominates the Allegory of Bad 
Government. The landscape takes on an ethical dimension in Lorenzetti: it is not the undifferentiated space made of dull matter of Descartes (Chapter 2), it is rather a man-shaped place, a place made better or worse by the value-imbued choices taken by the citizens: space too is either virtuous or vicious.

Before we delve into the significance of this work for contemporary PA, we should address a preliminary methodological question: can we use artistic works, and notably works from the past, for advancing our knowledge and understanding of PA? What is the philosophical foundation of using a work of art, in the case a work of visual art (a series or cycle of paintings) dating back about seven centuries, to advance knowledge and understanding of contemporary PA? Following Drechsler, we argue that we can, because:

[T]his is superbly explained by none other than Hans-Georg Gadamer: 'art is the overcoming of the past. All is presence in art. It becomes presence' (Gadamer, 1997: 25). This is so because art is only 'there' during 'the act'-interpretation, in the sense of engagement, is what makes the work of art. This is a-temporal; if we look seriously at, and engage with Lorenzetti's fresco - ... it becomes alive at that moment, and on a level that is neither merely aesthetic nor purely intellectual or historical. (Drechsler, 2001a: 7/8)

A related way of arguing about the significance of art flows from Martin Heidegger's conception of every work of art, every masterpiece as a whole world, where the unveiling of Being occurs through the engagement of the beholder with the masterpiece.

Works of art may be verbal (like in poetry) or non-verbal, like in the figurative arts. Not all knowledge is verbal; indeed, an essential part of knowledge and understanding is inherently non-verbal, ${ }^{1}$ and possibly PA has drawn too little from non-verbal knowledge (although, just to mention familiar examples in the cognate field of private management, Mintzberg et al. (2009) widely use graphic, non-verbal communication as a form of expression of knowledge). Hence, an understanding of public governance and public administration may be enriched and enhanced by engaging with artworks, and notably also non-verbal artworks.

In recent times, this approach has been advocated and efficaciously propounded by scholars like Wolfgang Drechsler ${ }^{2}$ and Gjalt de Graaf. Through the works of Drechsler and de Graaf, debating Lorenzetti's masterpiece has become a mainstay in the PA literature (Drechsler, 2001a; de Graaf and van Asperen, 2018). Drechsler and de Graaf use Lorenzetti's frescoes not as an illustration, but as the core of the argument (Drechsler, 2001a). De Graaf's main research question is:

How can Lorenzetti's frescoes of Good Governance inspire our modern-day conception of good governance? [and] In the search for insight into the concept of 
good governance, our goal is to see whether the frescoes can help us develop a fresh perspective on what makes governance, good governance. We use the hermeneutics of art. (de Graaf and van Asperen, 2018, pp. 40-8)

In further elaborating on the possibility of using art in PA scholarly work:

Following this line of thought, under the right circumstances the analysis of a work of art can lead to inspired insights. In art history, images - paintings, statues, prints or miniatures - do not serve as illustrations of 'how it used to be.' On the contrary, the image, its context, and its intended audience(s) are the points of departure which, combined with other archival, literary, and visual sources, expose the concepts and practices of its day, both intentionally and unintentionally. Works of art show ways of looking at the world that might seem strange to modern eyes. They offer an unfamiliar view, and that is exactly why they can be inspiring. In the case of Lorenzetti's fresco on good governance, the discussion should involve both art historians and public administration scholars. Only when an argument integrates a thought through interpretation of iconographic detail and a vision which goes beyond the purely historical, does it become a serious discussion about the inspirational power of imagery. (de Graaf and van Asperen, 2018, pp. 408-9)

What teachings can therefore be drawn from a contemporary reading of The Good Government for the purposes of advancing contemporary PA - by inspiring and generating understanding? ${ }^{3}$

Key virtues in the Christian tradition, both 'civic' and 'human' tout court, are Prudentia (Prudence), Fortitudo (Fortitude), Magnanimitas (Magnanimity), Temperantia (Temperance), and these are deeply linked to Iustitia (Justice) and Pax (Peace) and Concordia, which can be translated as Harmony or, possibly better in the context of this work, Unity or Concord (the Latin etymology of concord being: the hearts lying together, the togetherness of hearts). The key 'argument' (expressed in visual form) of the Good Government is that the common good can be achieved only when these virtues are practised, notably by the governors (the painting is in the 'Room of the Nine', the meeting room where the nine governors of the Republic of Siena of the time met and deliberated on the governing of the city, in their duty of office taken up on a rotating basis). The judgement of the author has been left open about how much the practice of virtues by the citizens is also decisive for the positive effects of good government to manifest themselves (as it seems to be suggested by the fact the rope that is passed from the Justice realm via Concordia by the citizens ties the hand of Good Government that holds the sceptre 4 ), or whether 'virtuous government' may remedy the lack of public engagement and commitment to the common cause by the citizens - although evidently Lorenzetti is concentrated on the effects of governmental action, and hence on the practice of virtues by governors. For this reason, the represented virtues are primarily intended as the governors' virtues: the very location of the murals in the City 
Hall is testimony to this meaning. However, the people of Siena are widely represented throughout, and hence virtues might well be interpreted as being in equal measure citizens' and governors' virtues - a message that echoes ancient Greek philosophers on the constitutive linkages between individuals' virtues and civic virtues, and hence on virtues of all citizens, ${ }^{5}$ as well as echoing modern and contemporary republican thinking on the requirement of citizens practising civic virtues and exercising their 'positive freedom' and partake to the common sorts of the political community.

The qualification of 'good' government may also be noted - not 'best', 'excellent', 'cool' or whatever other superlative tends to be fashionable nowadays. 'Good' is inherently a non-comparative concept, which is not 'better' than somebody else's government or 'best': the practice of virtues leads to the common good across places and times, although the magnitude of the effects may be variable depending on the relative wealth of the country, the proclivities and talents of its citizens, and the like.

The depiction is also about 'government', not governance. This may be due simply to the consideration that as a matter of fact the distinction between government and governance is not expressible through two distinct words in either Latin or the Italian language (this also applies to 14th century Italian), but the emphasis on the well-functioning army (typically an area where, it may be argued, governmental direct action does matter) as a condition for the secure development of the political community is testimony that the emphasis is at least on par on governmental action as it is on the broader good governance.

Logical connections may be drawn amongst the virtues. It is primarily from Wisdom and Justice that stem the conditions leading to the common good and a thriving political community. However, once this status is provisionally achieved, in order to maintain and protect it over time Fortitude is required, to maintain incorrupt behaviours and ultimately protect the common good from enemies arising both from the outside and from within the community. In fact, unity in the community is highly valued and upheld, also by physically placing it centre stage in the painting: this is indication of the significance attributed to the virtue of Concord. The significance of concord may be better appreciated in light of an interpretation of the world-famous Palio di Siena, the competition that every year sees all the districts of Siena, or contrada as they are called, in a horse race in the municipal square, Piazza del Campo (an architectural masterpiece; see Figure 7.2). This is a heart-felt competition, very far from fair play, and the jockey is either extolled if he wins or lampooned by district-fellows, even ostracised, if he fails to win (ostracism, at least symbolically if nowadays not physically, happens to all jockeys, ${ }^{6}$ but the winner - because second place is no consolation - and only the allure of being the idol and icon of the contrada drives youngsters to train as jockeys in defiance of the likelihood to become forever labelled as 'loser'). This race dates back to about 
one century before Lorenzetti painted his famous fresco, and it can be stated that the spirit and the inner dynamics of life in Siena as they manifested themselves in the Palio were surely well-known to him (although other historians disagree as to the significance of the Palio as we know it today during the times of Lorenzetti; Drechsler, 2001a). How to keep the city of Siena united in the presence of so intensely felt local, district-level identities, and in spite of such harsh competition between its constituencies? The key message stemming from the painting - which would sound like music to the ears of ideologists of federalism and federal polities in the larger sense - is that the autonomy of local units, their self-organisation, their role as provider of 'welfare-related' services, and last but not least their capacity to generate what in contemporary terms (and to mention a famous study whose field evidence comes from Italy; see Putnam et al., 1993) is labelled 'social capital' are highly valuable things - subject to only one, yet crucial, condition: that they do not undermine the overall unity of the superior political order, the city itself. Hence, the prominent place given to the virtue of unity, or concord, in the painting. Indeed, you win absolutely nothing at the Palio: it is an identity-building exercise, but also an opportunity to channel rivalry into games, rather than having divisions to seriously undermine the substantive unity of the city.

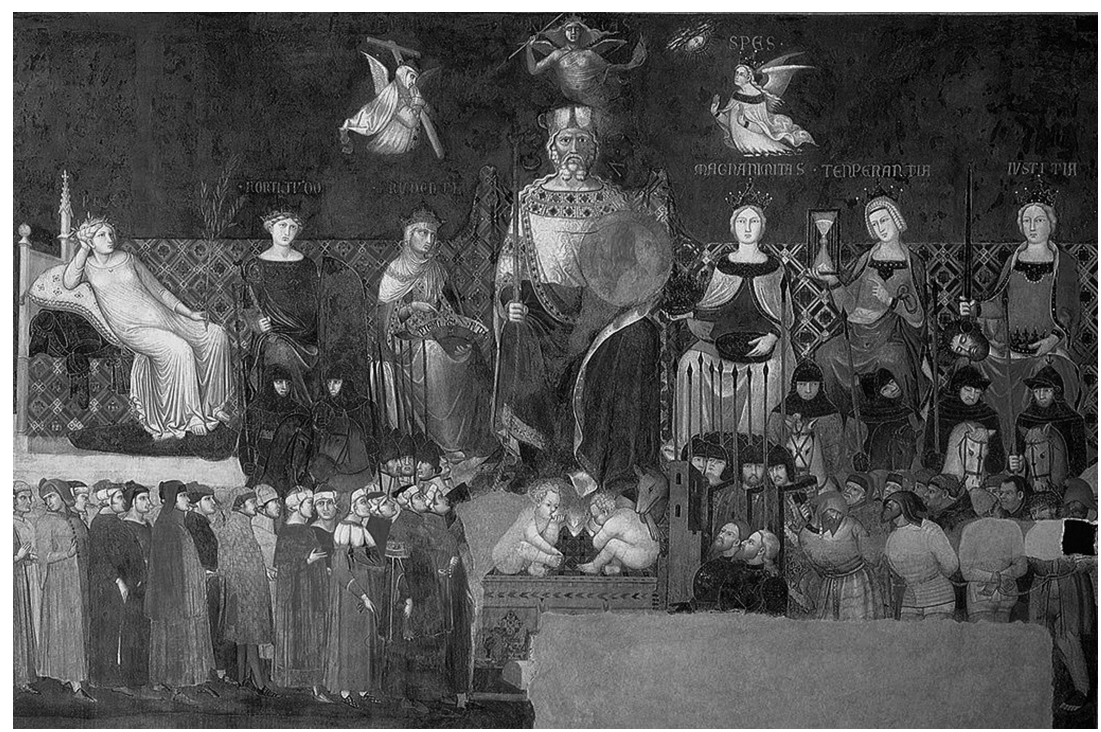

Source: https://commons.wikimedia.org/wiki/File.Lorenzetti_amb._good_government169_det .jpg (accessed in 2017).

Figure 7.1 Allegory of the Good Government 
A final question may appropriately be asked: who pays (Drechsler, 2015a)? In much more recent times the Italian banking sector ran into trouble due to the hypertrophy and expansionist appetites of one of its largest banks, and the oldest bank not just of Italy but of the entire world: this is the historical bank of Siena (named Monte dei Paschi di Siena). The reason of this recent-times near bankruptcy lay also in the greedy behaviour of those in charge at the time, at least some of them: vice replaced virtue, notably replaced the fourth of the cardinal (main) virtues: temperance. Commerce and services, thriving at the time in Siena, contribute to the well-being of the political community by bringing wealth, the much-needed wealth that pays for public welfare and services as well - but these arts require to be practised under the guidance of the virtue of temperance, without ever giving in to greed: a rule of behaviour, which of course equally if not primarily applies to those in charge of ruling the city.

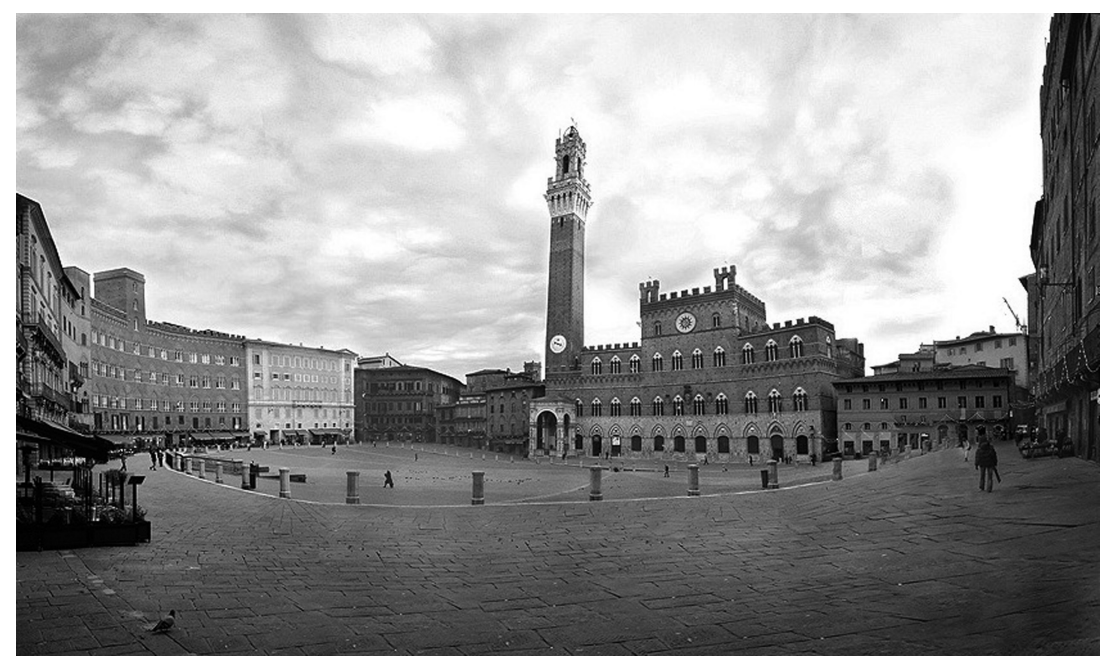

Source: $\quad$ https://commons.wikimedia.org/wiki/File:Siena5.jpg (accessed 17 April 2020).

Figure 7.2 Piazza del Campo, Siena, Italy

Alongside cardinal virtues, Lorenzetti's frescoes also give much emphasis to the so-called 'theological' or biblical virtues. Before concluding, it is worth dwelling on the consideration of the significance of theological virtues in the 
Allegory. We leave the floor to de Graaf, who aptly noticed and elaborated on this point:

As a departure from other public administration studies on images of good governance (with the notable exception of Drechsler, 2001), we begin here with an analysis from the art historian's perspective. A careful examination of that part of the fresco that depicts the Allegory of Good Governance reveals that there are some elements in the fresco that have so far received little attention in secondary literature, despite the extensive scholarly awareness of the fresco. These underexposed aspects are the biblical virtues of faith, hope and charity. Today these virtues are often ignored in governance studies that mention the frescoes (e.g. Hendrik and Drosterij, 2012; Drechsler, 2001; Liebling, 2010), probably because they don't fit current views of what good governance entails. In the literature of art history, they have been noted, but have been branded as 'less central' than the other virtues, 'somewhat removed from the main scene' (Rubinstein, 1958: 180). Even those scholars who have recognized the important position of the biblical virtues more fully (e.g. Von Thadden, 1951) have not tried to establish why these were incorporated at a time when faith, hope and charity had not previously been components of the imagery of good governance ... In our view, the biblical virtues are more vital to the fresco than generally recognized in art history (or public administration or political science) studies. Every last element in the fresco has been carefully chosen and there is no reason to assume that the biblical virtues were incorporated without thinking them through thoroughly: Lorenzetti incorporated them for a reason ... The biblical virtues deserve careful consideration here, too, because they offer a different and supplementary view, not just of the fresco itself, but also of what was regarded as good governance. (de Graaf and van Asperen, 2018, pp. 409-10)

Representing good government was not unique to Lorenzetti's frescoes. But Siena was different from kingdoms and empires where the ruler was entrusted absolute power: Siena was a city state, an innovative form of administration in which at least a portion of the population, the aristocratic families, were actively engaged in government, notably through a mechanism or rotation into high office. Power had become more impersonal, it was not embodied by one person, the emperor or king, but rather transferred to institutions. These institutions, however, were to be run by human beings, on whose virtuosity of behaviour the well-being of the community depended. For this reason:

In order to depict good (and bad) governance, Ambrogio Lorenzetti adapted the traditional ruler portrait to represent a group of people instead of only one person (Rubinstein, 1958: 181). As in traditional ruler portraits, an enthroned male figure is surrounded by female personifications of the virtues that were associated with good governance. But unlike former and contemporary ruler portraits the male figure is not an historical person, nor a living ruler; he has divine features reminiscent of images of Christ ruling the world as Saviour (Skinner, 1999: 11-14). In short, Lorenzetti was depicting a personification of the Good Ruler, a secularized counterpart of the heavenly king ... He is both a figure of authority and a visualization of 
that community to which the governors should subordinate their own interests. He is both ruler and servant. (de Graaf and van Asperen, 2018, pp. 410-11)

And how does the behaviour of the ruler relate to the biblical virtues? The nexus is for Lorenzetti constitutive, in fact:

Lorenzetti depicts the three theological virtues [Faith, Hope, Charity]. Lorenzetti gives them pride of place with charity at the top according to St Paul's ranking: 'And now there remain faith, hope, and charity, these three: but the greatest of these is charity.' (I Cor. 13.13) ... But what, then, does charity entail to merit such an important place in Lorenzetti's fresco and to suggest that it is a significant element in good governance? Today, charity is mostly regarded as the love of one's fellow man. Charitable acts are directed towards fellow human beings. In Augustinian times, however, the virtue of charity was regarded as the love of one's neighbour, but also as the love of God (Augustine, Narrationes in Psalmos, Patrologia Latina XXXVI.260: 'Amor Dei, amor proximi, charitas dicitur'). Without the love of God, it is impossible to love one's neighbour, and the other way around. These are two inseparable sides of one coin. Augustine regarded charity as the virtue to uplift mankind and reflect man's closeness to God, because the love of man was a reflection of God's love of mankind. Christ had offered himself for the sake of human beings. Only the grace of God's love makes it possible for human beings to love. By loving one's neighbour, a person could imitate Christ and get as close to God as humanly possible. The virtuous life thus transcends earthly boundaries; it conducts the soul to God, where it longs to be, as Augustine argues (Augustine, De Civitate Dei, esp. ch. 6, PL 41, cols. 757-760). In Lorenzetti's fresco, charity is not only depicted as the most important Christian virtue, as Paul had emphasized, but the most important virtue of a Christian ruler ... Guided by charity, both the love of God and the love of mankind, inextricably connected as warp and weft of one fabric, the governors could elevate the commune and all her members and bring them closer to God. This ideal, heavenly, state is anticipated in charity's upturned gaze. Depicted at the top of the pyramid of virtues, she is the link between God and men. What is the purpose of it all? What would be the outcome if those involved in government let themselves be inspired by the picture of the ideal that Lorenzetti painted for them? In the middle of the fresco, between divine justice and the Good Ruler, Lorenzetti added the personification of peace which is the effect or outcome of good governance. The preservation of harmony and peace was certainly considered the most important task for the nine who presided over the commune of Siena. At the beginning of the oath of office taken by the nine they swore to "provide that the commune and people of the magnificent city of Siena are, and are preserved, in good peace and concord' (Waley, 1991: 47; Bowsky, 1981: 55). In his allegory, Lorenzetti shows the council members how to contribute to this peaceful state. The presence of peace underlines that his is not just a guidebook containing rules that the governors of the city state should follow in order to be 'good,' but he is providing an image of 'good governance' that incorporates both its prerequisites and its effects. To sum up, good governance results from virtuous governors who place charity before everything else. From charity all other virtues follow and without charity the other virtues are meaningless. The love of God and the love of men that make governors a reflection of the supreme judge are both essential to the achievement of peace on earth, of an earthly paradise. (de Graaf and van Asperen, 2018, p. 413) 
In sum, de Graaf's and Drechsler's arguments are about tying together ontology, behaviours and effects: good virtues lead to good government and governance, which manifest themselves in the well-being of the community; conversely, vices lead to poor, even wicked, governance. Within this frame, de Graaf's argument emphasises the actuality of benevolence and altruism, and their roots in the virtue of charity (in a Christian perspective). This topic might seem afield in PA, but it is not: 'PA scholars like Frederickson and Hart (1985; also Frederickson, 1980, 1997; Hart, 1974) argue for an ethic of civic humanism centered on the virtue of benevolence' (Esquith, 2006, p. 537). To make their case, and referring to contemporary democracy in the US, Frederickson and Hart (as aptly summed up by Esquith, 2006, pp. 538-9):

[U]sing the striking comparison between Nazi bureaucrats and Danish civil servants during World War II, they argued that while the former had lost any feeling of moral responsibility to a regime that was a corrupt charade, the Danes under Nazi occupation continued to feel a 'profound commitment to the democratic values of their nation and genuine love of the people' ... Therefore ... The 'special relationship' that must exist between public servants and citizens in a democracy is founded upon the conscious knowledge of the citizens that they are loved by the bureaucracy.

This position (which in a number of respects comes close to that of the 'existentialist public administrator', see Chapter 4) predicates of public administrators to interpret the fundamental 'regime values' of the country and to always gauge the way in which they are carrying out the policies they are enjoined to effect against these values - suggesting that ultimately the 'glue' that enables public administrators to effect those values is benevolence. The centrality of charity for 'good governance' is both a contemporary concern and a theme of active investigation. It is a mainstay in politics and PA that has long been recognised, not least by Lorenzetti's masterpiece.

Finally, it may be claimed that virtue-inspired government and governance has only the sky as its limit: it is literally about striving to achieve 'perfection'. The thrust towards perfection is inherent in the virtue discourse and present since Plato's and Aristotle's philosophical speculation on the just society. The masterpieces all around in Siena and elsewhere across Italy, in public spaces and churches, acted as powerful reminders - to Ambrogio Lorenzetti and also to his fellow citizens - of a common, diffuse effort to strive towards perfection and the divine that was driving the minds and hearts of the peoples of Italy during a period in which signories and city-states were flourishing across the peninsula (paving the way to the Italian Renaissance).

The roots of virtue politics - and virtue administration - are commonly ascribed to Aristotle. Aristotle distinguished between moral virtues (in which reason tempers emotions and passions and finds the proper balance of the opposite poles to steer the behaviour of humans as 'rational animals') and 
intellectual virtues (in which reason pursues its own goal: contemplating truth and being; and thus the human being as 'rational animal' fulfils itself by achieving contemplation), arguing that both are necessary for a happy life - where happiness is fundamentally intended as the fulfilment of our very human nature (the notion of eudaimonia discussed in the previous chapter). In this perspective, practical and contemplative wisdom figure prominently in the painting: in contemplating the eternal Being (in capital), human beings partake of the very eternity of Being. It is a philosophical tenet that would be widely taken up during the Renaissance.

Continuing a tradition dating back to the ancient age, ${ }^{7}$ virtues are centre stage in medieval thought as the basis of any good government, harmonised with Christian values and derived in a deductive fashion (from the Bible or by means of reasoning). In the late Middle Ages, theological and cardinal virtues come to be flanked by more mundane virtues (like liberalitas, magnificentia, majestas - liberality, magnificence, majesty - in De Principe Liber by Giovanni Pontano), and in this expanded conception continue throughout the Renaissance to be centre stage: the centrality of the practice of virtues and wisdom is reasserted in works like Erasmus's The Education of a Christian Prince.

It is during the Renaissance, however, that some form of divorce between the virtue discourse and 'realism' starts to creep in: Renaissance writers asked questions that would be treated later in an unconventional (at the time) way by Machiavelli: is it better for the prince to be beloved or feared? Are 'public' virtues distinct from 'private' virtues? (as argued by Francesco Patrizi in De Regno et Regis Institutione Libri IX). It is in this cultural climate of questioning the virtue narrative that Machiavelli would sharply distinguish moral virtues from political virtues, as we shall see.

The debate in the Renaissance in Italy was also about whether virtues hold an 'absolute', unconditional merit in producing 'good effects' or whether and to what extent they need to combine with the 'appropriate' constitutional form of the state (e.g. republic or principality)? Put shortly, the question was about what matters more: the virtues of the prince (the governors in general), or the constitutional form? Questions like these laid the ground for the birth of 'modern' political science, and, on a more mundane and everyday level, they are still echoed throughout manifolds strands of the contemporary social scientific literature, for example over the relative bearing of 'leadership' versus 'organisational design' - although the roots of these debates in Renaissance thinking are seldom recognised, and such oblivion is hardly beneficial to the social scientific contemporary discourse.

The contemporary reader will find the virtue debate very much broader and 'loftier' than the one s/he is accustomed to, which is more often framed in terms of 'public values' and 'value systems' in the public sector (see Bozeman, 
2007; Frederickson, 1997). Jørgensen and Bozeman (2007) have produced a detailed inventory of values in the public sector. The 'public values' discourse is partly close to virtue discourses in the classic, medieval and Renaissance sense, which continues on to our days - but contemporary social scientific research has added an attention to the empirical implications of practising values (virtues) in the contemporary, hyper complex administrative and societal systems. Authors have pointed to public value conflicts (e.g. between procedural values and performance values, see de Graaf, 2014; the special issue edited by van der Wal et al. 2011; van der Wal and de Graaf, 2010) and the problem of prioritising values and clusters of values (Rutgers, 2008a, 2008b; Jørgensen and Rutgers, 2015). Van Wart (1998) highlights certain properties of value systems in the public sector: they are especially complex, they derive from multiple sources - individual, professional, organisational, legal, public interest; they also serve as instruments to accommodate multiple interests; they change over time; they are subject to competition and they are contested. These ways of conceiving of public values is surely more attuned to the ears of the contemporary reader in their being drawn from different sources and 'bespoke' to different target groups and goals - but it may miss important teachings of the virtue discourse as has been practised during the Middle Ages and Renaissance.

One of the many reasons why such is the case is that, with the encounter of modern age, virtue philosophy also (re-)encountered hedonism, relativism and the centrality of individual subjective preferences, perspectives that are at odds with the virtue discourse. Interestingly, hedonism was also the main target of Aristotle's discourse, thus perhaps suggesting that in the terrain of the foundation of what is 'proper' behaviour for the promotion of the well-being of a community it is hard to set the debate on entirely new ground, and much of the foundations have been laid over the past two-and-a-half millennia. It is true, however, that in the encounter with the modern age, virtue philosophy has also met novel challenges: one is the analysis of (unintended) social consequences, like in Adam Smith's classical argument about the pursuit of private interest serving the needs of people better than public virtues - although it is hard to imagine Lorenzetti contenting himself with the statement of fact that the butcher maximising her/his interest may serve her/his country fellows better than the virtuous governor. Instead, Lorenzetti would remind us of the bad effects to be expected if greed dominates citizens' lives. However, it is unquestionable that social scientific investigations shedding light on such realities as 'unintended consequences of purposive social action', the influence of economic structures on social behaviour (as in both Marxian and some neo-liberal, economistic trends), and the like, may have a displacing effect on the virtue discourse, and that somehow such discourse has lost the upper hand over the past few centuries, and is struggling to recover the centre of the stage. 
A state of affairs that the author of this book thinks is a major loss: for public discourse, for the well-being of public communities, and for the field of PA.

There are, of course major attempts at incorporating the virtue discourse into contemporary social scientific research on public ethics, by such authors as Lawton, van der Wal, Hubert (see recently Lawton et al., 2016). Some authors make explicit reference to the virtue discourse and its place in contemporary public administration and management (Lynch and Lynch, 2006). The public ethics discourse has taken multiple directions: from public service ethos to the status and significance of code of conducts or the meaning of the oath of office; from individual behaviours to integrity systems, coupling ethical concerns and a systems theory approach, in order to analyse and 'manage' integrity in the public services, and so forth (Macaulay, 2018).

Possibly the one application of the virtue debate that is of highest contemporary visibility and resonance in the public debates is the one on (anti-) corruption: what behaviours should be effected for contrasting corruption in the public sector? Suggested remedies range from additional regulation and enhanced oversight to enforce the rules; to economics-based analysis of 'convenience' of corruptive/corrupt behaviours to try to design systems that provide disincentives to corrupt behaviours; to social-psychology approaches pointing out value-formation processes and critical junctures in the professional life when values held by the individual may shift; to the influence the organisational environment wields on values and behaviours. Such social scientific, analysis-based recipes are of utmost importance for describing social phenomena and identifying causal links and chains that lead to more (or less) desirable outcomes, thus potentially enabling remedial interventions. However, the masterpiece of Lorenzetti - and broadly the millennia-old reflection of virtues in government - act in this frame as a powerful reminder of the importance of not losing sight of the broader perspective: good government and good governance require more than properly engineered systems (e.g. for combating corruption, for ensuring compliance with the laws, for instilling 'appropriate' behaviours in public servants, etc.), however important they may be (and they are extremely important). Wisdom and justice, temperance and prudence, and charity, remain of overarching significance for the advancement of the well-being and for political communities that enable and nourish the fulfilment of lives.

Two final remarks conclude this section. First, a note to distinguish between public values 'in the plural' - the subject of the virtue discourse developed throughout this section - and public value 'in the singular'. Public value in the singular concerns the 'outcome' of public organisations, the 'results' or impacts generated and delivered to the (variously denominated) citizens, users, customers, clients and the like. It brings with it issues of how to 'measure' the outputs of public organisations and their impact: the valuing process and 
encompassing whom in such process. Public value is probably nowadays most famously associated with an attempt to measure the impact of public action on public needs, collectively identified and selected through democratic means, put forward by Mark Moore (1995). Various authors have worked on this and related themes, notably in the Benington and Moore (2011) edited work, who also emphasise the collective good of future generations, an attention which resonates widely in the virtue discourse, as already discussed in Chapter 5; notable works in the public value stream of inquiry include Alford et al. (2017); Hartley et al. (2017); and Talbot $(2010,2011)$. Interestingly, the very notion of public value is in this stream of scientific inquiry defined in both 'subjective' and 'objective' terms: public value is defined as 'what the public values' as well as 'what is objectively of value'. In the first perspective, a subjective take on the question 'what is public value?' is adopted by answering 'what the public values' (Benington and Moore, 2011, pp. 42-3) and by deploying the distinction between market value and use value, asserting the position that the public value approach resorts to the notion of use value: what is the value of usage for somebody, not how much somebody would be ready to pay for it (also on the grounds that public services are generally delivered in non-market contexts, without a selling price). Second and complementarily, an objective take on the question 'what is public value?' is taken by answering that public value is 'what adds value to the public sphere' (see pp. 43-6), stressing that public value is not concerned only with individual interests and some sort of aggregation thereof, but also and crucially with the wider public interest and the longer-term public good, including the needs of the generations to come. It is especially in this second meaning that the notion of public value becomes broader than the measure of the individual outcomes (as are the notions of 'use value' alongside the one of market value). Also, in revisiting Moore's 1995 work, it is not only public managers to be creator of public value, rather a wide range of stakeholders. Key notions here are those of co-production and co-creation: so for example, car-sharing arrangements may create public value by providing both effective transportation services (what the public values) and benefits to the environment, and thence also to the future generations (what adds value to the public sphere), and this occurs by having local public authorities and residents working together to co-produce the service of car-sharing, and preliminarily to that, to co-create the governance arrangement of car-sharing, by contriving the best form the delivery of the service can take.

Attempts have been hinted at suggesting how to bridge the public value debate with public values and indeed public virtues (an interpretation of the public value creation approach associated to Moore is that 'at the core he sought to understand what citizens expect from public managers and how the pursuit of virtue is incorporated in executive activities', see Liddle, 2018, p. $\left.969^{8}\right)$. This appears to be an important and promising path of inquiry. 
In concluding this section it is required, from a social scientific standpoint, to pinpoint the nexus between social action and the virtue discourse. Following the analysis developed by Virtanen (2018) about the ontological-logical structure of practical situations in administration, we may question what is the link between the virtue discourse as predicated across the epochs - from Aristotle to the Stoics during the Hellenistic epoch, to the Middle Ages and Renaissance and onto our times - and social action and administrative behaviour as we are more accustomed to intending it, after the seminal works of the fathers of contemporary PA like Max Weber and Herbert Simon. Condensing the issue into a question: how do virtues - to the extent they are a 'property' of the person who exercises and practises them - transform into social action and ultimately engender social effects? We can, in the space available here, only take the very large brush and sketch a few elements that may be useful to tackle this big question.

Social action is a key, defining notion for the discipline of sociology as well as across the social sciences, including PA, which has as one of its main foci the understanding of administrative action and administrative behaviour. Max Weber (1978/1922, p. 4) defines social action as follows: 'We shall speak of "action" insofar as the acting individual attaches a subjective meaning to his behaviour - be it overt or covert, omission or acquiescence. Action is "social" insofar as its subjective meaning takes account of the behaviour of others and is thereby oriented in its course.'

Intentionality plays a key role in this perspective, as does the assumption of instrumental rationality whereby the actor chooses a means in order to achieve an end. To the extent the actor's behaviour follows his or her understanding about which course of action contributes to the achievement of the end, the action becomes evidently understandable. It is intentionality about what ends to pursue combined with the rational selection of means conducive to the valued end that explain the actor's behaviour. Only in instances where the actor does not follow his or her beliefs and knowledge about effective action, do we need a causal explanation: the observed deviation from rational-instrumental action may be attributed to such factors as 'misunderstanding, strategic errors, logical fallacies, personal temperament, or considerations outside the realm of strategy' (Weber, 1978, p. 21).

If we interpret intentionality in the virtue perspective, the virtuous governor or citizen will have her or his value judgements inspired and shaped by virtues and the pursuit of perfection, and the course of action that follows will mainly lie in the selection of the instrumentally more apt behaviours, out of the range of the alternatives available to the limited rationality of the decision-maker, that allow fulfilling virtuous behaviours - virtuous in both their judgements about values and their factual judgements. Crucially, these alternatives will be reviewed in light of the inspiration stemming from the practice of the 
virtues: is the provisionally chosen course of action inspired by prudence? Is it informed by criteria of justice? Is it enlightened by a wise understanding of the situation? The task of the social sciences, and notably the field of PA in our case, in this perspective lies in explaining deviation from rational action and behaviour, either due to a fault of instrumental rationality, whereby the selected means turned out to be inadequate for the task because of misunderstanding, lack of knowledge, fallacies, or else; or due to deviation from virtuous intentionality, whereby value judgements turned out to be flawed - fault ultimately being detected by the perverse effects the ensuing course of action begets, as in the second part of Lorenzetti's painting where the effects of bad government are illustrated. Bad effects may be due to a fault in factual judgements (instrumental rationality) as well as in value judgements (intentionality), and the two are intermingled in the virtue perspective. Virtues inspire value as well as factual judgements, and the two are in a sense 'kept together' by the practice of virtues.

A sharp distinction between value judgements and factual judgements is instead drawn by Nobel Laureate Herbert Simon and nowadays permeates the social sciences and PA. For Simon, value judgement is about 'ought to dos' - what should be done or made to exist; and 'you can't get an "ought," by any manner of careful reasoning, solely from a set of pure "is's" (Simon $1947 / 1997$, p. 68). Value judgements and factual judgements belong to two distinct dimensions, and the analysis of one (factual judgements, the remit of social science) can commence only when the other (value judgements) ends. Does this statement hold from the viewpoint of the virtues perspective? Can the virtue discourse be sub-divided between factual judgements (instrumental rationality) and value judgements in so sharp a way as Simon has claimed? Very tentatively, perhaps it may be put forward that the virtue perspective goes the opposite way: it rather strives to integrate the two kinds of judgement, or at least it has an overarching thrust towards keeping the two forms of judgement together: the 'oughts' and the 'is's' are inextricably linked. Is this one reason why 'modern' social sciences (at least in the notion generally accepted by the followers of Simon) and millennia-old virtue discourses seem not to be able to communicate with each other? Is this the root of the chasm, the gulf between the two (and between the followers of Simon and those of Dwight Waldo, whose work might be interpreted as in closer continuity with the millennia-old 'public virtues' discourse)? Those are crucial questions, and huge ones - to be much more fully tackled by other books, by other authors - but revisiting the works of virtue philosophers, and painters like Lorenzetti, represents firm ground on which to stand for tackling such questions.

There is another major challenge to the virtues discourse: it comes not (only) from distinguishing the realm of 'values' from the realm of 'facts', but instead it questions the extent to which virtues inspire behaviours. The realism critique 
of the virtue discourses is a warning about the meanness of human nature and the ensuing impracticability of virtues, particularly when it comes to public behaviour, at least as much as it is a warning about the risks of overlooking instrumental rationality when virtues are placed centre stage. The intellectual work of Niccolò Machiavelli is an all-rounded manifestation of such questioning of the virtues discourse: it is to his foundational work we now turn.

\section{NICCOLÒ MACHIAVELLI AND REALISM}

Machiavelli is a sharp critic of the sustainability and expediency of the exercise of ethical virtues for the cause of building and safeguarding states. Niccolò Machiavelli ${ }^{9}$ was born on 3 March 1469 in Florence and passed away on 21 June 1527. He was appointed secretary of the Republic of Florence in 1498 and lasted until 1512, when the republic fell and Florence re-became a Principality with the Medici family re-instated in power. He since never returned to public office, notwithstanding many attempts pursued with sheer determination. It was in the aftermath of having been toppled from office that he conceived his masterpiece, Il Principe - The Prince, which takes the form of a letter addressed to the new ruler of Florence, Lorenzo de' Medici, having the purpose of providing him with advice for the most effective exercise of his role. Implicitly, The Prince is also a plea to be re-instated in office.

In his attempt to re-gain access to office, Machiavelli was less effective than his contemporary and country fellow Francesco Guicciardini, like him genius of the art of government, who after serving in the Republic of Florence later managed to serve in roles in the re-instated principality of Florence under the Medici family and for the Holy See. Machiavelli and Guicciardini represent one of the first examples, indeed exemplars, of the 'technician', the person whose skills and ingenuity in the art of the state and the possession of technical knowledge is put at the service of different political masters, always with the intent of perfecting, or at least improving, the workings of the state. ${ }^{10}$ The two main works of Machiavelli are The Prince and Discorsi sopra la prima Deca di Tito Livio (Discourses on Livy). The latter, mostly complete before The Prince, are reflections on the lessons that can be drawn from the works of the Roman historian Titus Livius (Livy), and notably on how to run a republic. It is not unlikely that Machiavelli conceived of the Discourses on Livy as a work whose utility also lay in preparing the politico-administrative elite in the event of a successful re-instatement of the republican form in Florence (his links with the cultural environment of the Orti Oricellari, an elite circle aiming at re-instating the republic in Florence, are well documented). Discourses on Livy tackle the problem of how to make an already existent state work: it is about the qualities a people must possess in order for its state and political community to thrive in an insecure and perilous world. The Prince (written, for the 
most part, at breakneck speed in 1513, just after having lost his post at the helm of the administration of the Florentine Republic of 1498-1512) is a reflection on the qualities that an individual, the Prince, must possess to gain and maintain power under different political regimes. It is intended as a textbook about how to set up a state and the role and function of the Prince as demiurge of the process. The backdrop of this is the prefiguring of the Italian state, beyond the many conflicting and weak principalities that populated the landscape of Italy in the 16th century, and that were under the de facto domination of the kingdoms of France and Spain. Ultimately, the inspiration and motivation of The Prince is idealistic and patriotic, ${ }^{11}$ inspired by the dream of the unity of Italy (which would materialise only three-and-a-half centuries after Machiavelli), and yet the content aims at being value-neutral: to teach the art of getting to power and maintaining it, and practising those qualities and behaviours that are required to achieve such goals. Within the setting of the problem of how to establish a new state, Machiavelli addresses the specific questions of 'how to get to power?' and 'how to keep power?'.

The Prince is articulated in thirty-six chapters, through which the argument unfolds as follows. Chapters I-XI outline a typology of principalities: they may be inherited or new acquisitions, self-standing or parts of wider domains, acquired by means of armies - owned or mercenary - or conquered by virtue or by chance. The one Machiavelli is most interested in is the brand new principality, as such would be a unified Italy under a prince. As we have hinted at, the main thrust and overarching motivation in writing The Prince and dedicating it to Lorenzo de' Medici lies in the fact that the Medici family was in power both in Florence and in Rome, and hence presenting a window of opportunity for the two most substantial powers in central Italy to coalesce and 'rescue' Italy from warfare, to ultimately re-unify it. Machiavelli was inspired in this vision by the consideration that the glories of ancient Rome, whose empire stretched across a huge expanse from the Middle-East encompassing the entirety of the Mediterranean basin to reach out to territories like nowadays England, first lay in a unified Italy under its control.

Chapters XII-XIV discuss the respective merits of mercenary versus own militias: the main argument here is that own militias - a proper state army - is a prerequisite for maintaining power. Chapters XV-XIX vet the virtues and behaviour proper for a prince: a well-specified definition of virtue is here adopted, far away from the notion of virtues depicted by Lorenzetti: virtuous behaviours are those that are useful for ruling the state - an instrumental notion of virtue in stark contrast with the medieval virtues discourse and any notion of harmony between moral behaviour and political behaviour. For Machiavelli, immoral patterns of action, like cruelty in deeds and deceit in words, may be functional to the goal of ruling the state, and in this sense may be considered as 'virtues'. This was not something unknown to rulers before 
him, but Machiavelli was the first to formulate the functionality of immoral behaviours for the purposes of ruling the state in both lucid and crude terms. Chapters XX-XXIII provide a range of precepts on appropriate behaviours for the prince vis-à-vis his advisors, courtiers, flatterers, and so on - putting a strong accent on the importance for the prince to avert flatterers. Chapter XXIV gauges the responsibility of the extant Italian princes and the reasons why they lost control of their states.

Chapter XXV is a most famous chapter. It contains a reflection on the relative influence of virtue and chance in shaping the course of human events: what is the clout of human action in shaping the course of things, as opposed to chance ruling events and the fortunes of the world? Machiavelli famously stated that 'fortune is the arbiter of half our actions, but that it lets us control roughly the other half', by which he meant that the outcomes of our intentional (social) actions are for a half determined by chance, but for the other half are shaped by our actions. He then sways in the way in which fortune is depicted; at times it is seen as a natural force, like the flooding of a river, which cannot be controlled when it bursts, but it can be controlled when the river is not in flood, provided men are industrious and savvy enough to take the proper precautions. It is, therefore, only idleness in taking precautions that makes chance have such a great say in the course of human events. Other times, however, Machiavelli appears more akin to conceive of fortune as a sort of zeitgeist, the spirit of the time or the set of circumstances in which the social actors operate. In this second perspective, it is the fit between the circumstances, on the one hand, and the temperament, natural inclinations and qualities, skills and mode of operation that is more congenial to somebody, on the other hand, that determines whether he or she will be successful. Certain epochs or sets of circumstances are more appropriate for prudent, reflective people; others require impetuous personality and audacity to be tamed. Whether we are born in a time that fits our natural inclination or not is a matter of chance, and it affects our fortunes in the pursuit of power. The chapter ends with a statement that it is more often the impetuous and audacious that win power, formulated through the famous (or infamous, for the sexist thrust of the prose, which does cause our eyebrows to lift) assertion that

fortune is a woman, and if you wish to control her, it is necessary to treat her roughly. And it is clear that she is more inclined to yield to men who are impetuous than to those who are calculating. Since fortune is a woman, she is always well disposed towards young men, because they are less cautious and more aggressive, and treat her more boldly. (The Prince, Chapter XXV) 
The final chapter, XXVI, is a passionate exhortation to free Italy (this chapter was written and added some years later, as was the dedication in the preface of the book to Lorenzo de' Medici).

Some key philosophical issues and quite strong assertions emerge with vigour from the works of Machiavelli. First, a negative assessment of human nature. The reckoning of the viciousness of human nature is in Machiavelli to be recognised as a 'matter of fact', something which whoever is involved in the business of the state must take into account for formulating more pertinent judgements. These judgements about the meanness of human nature apply to the political and administrative spheres as well: it is a lesson of pessimism about the motives and the behaviour of those who pursue a career in the public sphere, as well as about the motives and behaviours of citizens, those whom certain approaches in public governance and management pretend to be 'involved', engaged', 'committed', as well as disciplined and rational users of public services. This trait of human nature becomes in Machiavelli a datum, a matter of fact to simply accept: an approach that denotes a 'social-scientific' attitude towards political phenomena, which is why some credit Machiavelli as the founder of political science.

Second, a 'principle of realism' whereby facts have to be considered and treated in their own terms, as they present themselves and not as we wish or desire them to be, and hence a conception of politics as 'the science of the state', the body of applied knowledge functional to the establishment, development and 'maintenance in operation' of the state. This is a notion from which it is not difficult to derive that behaviours that are 'proper' are those functional to these overarching goals, and behaviours that are 'improper' are those that are dysfunctional to these goals - even when such behaviours are morally or ethically 'good'. There is here a sharp distinction and disjunction of 'honour' (meaning in the context of the epoch: moral, honest - honestum in Latin) and expediency (useful, utile), of what is honourable and what is expedient: a departure here from contemporary 15 th/16th century works and treatises for governors and princes that were collations of moral and ethical virtues. Moreover, 'even more unnerving is his seeming uninterest in seeking a justification beyond political success ... Machiavelli's insistence on the tension between the demands of morality and the demands of political practice is more than plausible, but it is unnerving because he left that tension visibly unresolved' (Ryan, 2012, p. 358).

As a footnote, it arises from this picture that the simplistic statements made by duplicitous politicians citing Machiavelli as excuse for the light-hearted undertaking of behaviours of dubious morality find no ground in Machiavelli's original work (whom they are very unlikely to have ever read). Nowhere in Machiavelli's work can be found the sentence 'the end is justification for the means' (in itself quite a stupid statement: a means is a means to an end by defi- 
nition); rather, the reader is left brooding on this unresolved tension between the logic of morality and the logic of expediency, the latter being the one that seems to hold the keys to the course of action that in this earthly world leads to grabbing and keeping power.

Third, grabbing power and achieving glory (which Machiavelli intended as 'entering History', in capital letter) is the key driver of human behaviour for Machiavelli, or at least for that portion of human beings who are keen to enter the political arena. For Machiavelli, 'power' and 'glory' are the unquestioned ultimate goals and criteria driving value judgements for 'politicians' - not improving public services or fulfilling ethical values, not even just the pursuit of the extraction of some advantages. The extraction of advantage as overarching goal - utility maximisation - is generally predicated by theories rooted in economics like the public choice theory (in this regard, whilst Niskanen's $(1971,1973)$ model of the bureaucrat as budget maximiser still bore some resemblance to power maximisation, Dunleavy's (1991) sophisticated bureau-shaping represents in a sense a departure: hiding and lurking in the shadow, exploiting information asymmetries to extract benefits is the behaviour of bureaucrats depicted here). Machiavelli reminds us that although there are those who adopt such courses of action when holding public office, there are also others in the political arena who more simply aim for the maximum of power and glory, for entering History; and this is a dimension of human action we need to cope with, and include in any understanding of public governance dynamics.

A fourth key theme in Machiavelli is the place that violence occupies in politics (and in PA): indeed, 'the readiness to say that political success demanded an unflinching willingness to violate every moral precept appropriate to private life as sharply as Machiavelli did was novel in Christian Europe' (Ryan, 2012, p. 358). Machiavelli brought to the fore violence in politics to an extent that was not unknown, but it was unspoken before him, it was something tacitly known (the ancient Romans didn't care much - at all - about the violation of their neighbours' human rights when they expanded their territory) but never made explicit, at least not as explicit as Machiavelli did, as in the famous (infamous from a moral viewpoint) statement: 'men should either be caressed or crushed, because they can avenge slight injuries, but not those that are very severe'.

Fifth, Machiavelli reminds us of the role of chance in human affairs: something that perhaps large swathes of contemporary social sciences tend to underestimate, possibly espousing at least implicitly a logic of determinism (even in its 'probabilistic variant') in the form: from X will follow Y under conditions Z. Chance is tamed under statistical treatment as 'noise' or 'unexplained variance'. But in most complex phenomena where social action occurs chance does play a role, as some of the most perceptive scholars remind us. 
(For the role provided for chance - chance events as catalysts or hindrances to reform - see Pollitt and Bouckaert (2011, Chapter 2) in their model of public management reform; for the usage of the notion of potential as distinct from the actuality of what happened in a given set of circumstances to account for 'success' or 'failure' in the analysis and extrapolation of practices in public management, see Bardach (1994, 1998); as aptly noticed by Bardach, successful cases perhaps happened by chance, but the same chance might not be replicated elsewhere - or vice versa a practice may have potential and be worthy of replication elsewhere, but things simply went wrong on that occasion, literally, 'by chance': which does not entail to dismiss the potential a practice may have.)

Sixth, Machiavelli makes a strong assertion about the immutability of human nature. Machiavelli, throughout the two works The Prince and Discourse on Livy, amasses evidence that such is the case when comparing ancient episodes with his contemporary 15 th/16th century Italy. From this, for Machiavelli, also derives the meaningfulness of learning from the 'successes' of the ancient Romans, both the republic and the empire, in their colossal state-building exercise (to which Discourse on Livy is dedicated). The immutability of human nature over time is for him the grounding of the very possibility of learning from the past, which in social phenomena would otherwise become pointless. We return to this point in the next chapter.

Finally, trivial as it may sound, Machiavelli reminds us that enlightened governors and administrators must, as a minimum, get to power and keep it for a sufficiently long time span before they are able to exercise the noble and sought-after reforms of public governance and public services for the betterment of citizens' lives.

\section{THOMAS MORE AND UTOPIA}

A radically different approach to the question of how to better public governance comes from the tradition of utopian thinking. The very usage of the word is to be credited to Thomas More's Utopia. This masterpiece was written in Latin mostly in 1515 , although a part possibly could have been drafted earlier in 1510, during a summer spent in Antwerp in the company of Peter Giles, an acolyte of Erasmus of Rotterdam, the great humanist and close friend of More. Its full title is De Optimo Reipublicae Statu deque Nova Insula Utopia ('On the Optimal State of a Republic and the New Island of Utopia'), and the first English translation dates in 1551 by Ralph Robinson, followed 'with more literary skill' by Gilbert Burnet in 1684, the version to which we refer here (but see also among others the version edited by George Logan, Robert Adams and Clarence Miller and published by Cambridge University Press, 1995). It was 
first published in Leuven in 1516, then in Paris (1517) and Basel (1518), but its publication in England occurred only after the passing away of More.

The term 'utopia' is derived from the Greek outopia, which means 'no place' nowhere; additionally, as wittingly noted, 'More exploits the punning ambiguity inherent in its similarity (especially if read in the English language pronunciation, our note) to eutopia, or "the good place"" (Ryan, 2012, p. 312, emphasis added). Although the mint is Thomas More's, there are illustrious predecessors to Utopia in the literary strand of utopian thinking, indeed as far back to Plato's The Republic, already encountered in the discussion of the common good foundations of governance, a work which was one of the powerful inspiration of Utopia. More's Utopia is explicitly inspired by Plato's The Republic, and indeed intellectually dedicated to the Greek giant of philosophy. The Republic is also a discussion about the significance of entrusting government to philosophers (or at least to governors well trained in philosophy). The main characters in the work, who are the same Thomas More and Raphael Hythloday, debate at length about Plato's recommendation (both characters display awareness of the same scepticism that Plato had about the feasibility of his own suggestion that philosophers be governors). Thomas More can, however, be credited to have been the first to have not just coined the term 'utopia' but deployed in full this conceptual tool. He was followed suit by other literates, including Tommaso (Fr Tomaso, born Giandomenico) Campanella who authored La Città del Sole (The City of the Sun, 1602).

The character of Raphael Hythloday in the plot is assigned the role of the person who, whilst travelling across the world, eventually moored in the island of Utopia and became acquainted with their mores and governance practices; he then reports to the same Thomas More what he discovered of this political system so altogether different from any other.

The book illustrates the governance arrangement of Utopia: the distribution of authority and procedures of appointment of the magistrates; the configuration of its towns, and the capital Amaurot in particular; the organisation of labour of Utopians (the inhabitants of Utopia) and their trade arrangements; their manners of life (some of them scary to the eyes of modern people, and not just them: for example the practice that family life is in common, whereby men never leave their house and women join them when they get married; or the compulsory permission to travel, which has to be granted by public authorities if a citizen wants to travel across the island, although the author immediately adds that if any man has a mind to visit his friends that live in some other town, or desires to travel and see the rest of the country, he obtains leave very easily ...' (p. 42)). The way in which Utopians deal with neighbours and manage war (the 'foreign and defence' policy of Utopia) is also discussed at length, as is their religion, and notably how they apply (with some qualifications) a regime of religious tolerance, wholeheartedly praised in 
Utopia. The significance of More's intellectual stance on religious toleration can only be reinforced by later events: Thomas More was beheaded by King Henry VIII and died a Catholic martyr for not forfeiting the Catholic faith and remaining loyal to the principle of the primacy of Papal authority. The utopia of religious tolerance, which had no place during More's lifetime, however, would eventually win the hearts, minds and constitutions of the peoples and the states all over Europe.

What is the 'usage' or 'function' of Utopias in PA? In Utopia, public governance enables the full-fledged development of all citizens, placing utopian approach firmly in the camp of common good notions of justification of public governance. In this line of teleological thinking, utopias may be seen as performing the function of driving behaviours towards 'perfection' and escaping decadence in the form of path-dependency sub-optimality. ${ }^{12}$ In this sense, utopias may be interpreted as 'guiding ideas' or regulatory ideas suffused with a normative tone: utopias enter policymaking, thereby including in modern times the reform of public governance, the state and public administration, as an ideational source. ${ }^{13}$ Utopias may perform a normative function about what could be done for bettering public governance. They do so because of the other function utopias perform: the function of a critique of the extant state of affairs by providing a comparator in the form of a world other, from which to critically revisit the extant governance arrangements of this world, of the given political system which is being examined (in the case of More's utopia, the governance arrangements under critique were those of early 16th-century England, which More depicts and harshly criticises in the first part of the book). The two functions performed by utopias - normative and critical - are complementary and mutually co-existing, with one enabling the other. One way of interpreting this link is to consider utopias as an alternative, holistic vision of public governance, which may be used for critique of extant governance arrangements, and then, based on value judgements and evaluation, a utopia may be used as a set of (more or less loosely connected) guiding ideas for purposefully changing the extant governance arrangements.

It is, in our view, important to emphasise that utopias may be seen as eliciting critical reasoning, and hence performing a maieutic function. Almost all aspects of the functioning of More's island of Utopia, far from being uncritically accepted, are questioned in his book. Later interpretations of utopian thinking (see recently Erickson, 2015; Jacoby, 2005) distinguish between blueprint utopias (fixed models of what perfect governance looks like) and iconoclastic utopias (sketched models that stimulate critical thinking beyond contingencies and escaping path dependency traps by acting as stimulus for critique of the extant arrangements). This conceptual tool has been employed for distinguishing 'good' and 'bad' utopias: in this reading, Plato's Republic is categorised as blueprint utopia, a fixed model which ultimately demands to be 
effected as it is, to be superimposed on pre-existing governance arrangements, which are for disposal. Iconoclastic utopias are instead aimed at eliciting dialogue and future-orientation, a forward-looking attitude that may enable 'thinking out of the box' and escaping path-dependency and repetition of the extant sub-optimal solutions; iconoclastic utopias are ultimately a tool for eliciting critical reasoning. Whether Plato's Republic falls under the blueprint rubric, and whether and to what extent a neat distinction may be made between these two kinds of utopias, is for the specialists to debate. However, there is no part of the story narrated in Utopia that falls neatly into the iconoclastic category: the inhabitants of Utopia cannot travel without permission and everyone is acutely conscious of being after the eye of everyone else. ${ }^{14}$ After Orwell's 1984, mutual surveillance means to us Big Brother, and restrictions to liberty 'seem to us much too high a price to pay, even for the peace and security it offers' (Ryan, 2012, pp. 318-19). We cannot know what More might have thought of this, but we may well reckon that an inherent risk of drift towards blueprint thinking is inherent in any utopian approach and, in this sense, the thought-eliciting work of More is a reminder of the ubiquitous risk that utopias become totalitarian by their very nature (a number of the features of More's Utopia do display totalitarian traits).

Indeed, the dystopias that have been put into effect over the 20th century have led to all sorts of slaughters and horrors against the most basic human rights. It is against this backdrop that poignant critiques of utopian thinking have to be set. Such critiques were famously expressed by the likes of Hannah Arendt (1971), Isaiah Berlin (1991), and Karl Popper (1963), who all saw in Plato's Republic - the ancestor of all utopias - the germ of totalitarianism and made the Republic the ultimate target of all the critiques to utopian thinking, deemed responsible of having inspired earthly hells, like Nazi death camps, the killing fields of the Khmer Rouge, the Soviet gulags, or the Maoist counter-revolutionary campaigns.

It may be claimed that it is mainly for this reason - the tragic evidence of utopian thinking leading to hell on earth - that utopian thinking has been side-lined and replaced by 'incremental' thinking, the kind of 'practice-that-work'-based thinking which is nowadays internationally dominant. But what about the original Utopia as More conceived of it? Can it be indicted as the source of dystopian thinking that followed? A large debate has arisen on More's work, and my foray into the topic is but a sympathetic one that will stress the facets of the original More's Utopia which, from this slant, seem to indicate that antibodies and remedial indications to pre-empt dystopias were already in his book. Other and more expert authors may well argue against this sympathetic view of Utopian thinking as it originates from More's Utopia; no doubt, though, the irony that suffuses More's Utopia and its comic element present throughout clearly point to its iconoclastic nature, 
critical of the laws and practices of the time - early 16th-century England. This seems to be the prevalent thrust (the first part of the book is entirely devoted to running a harsh critique of England's economic and political arrangements of the time, which are vetted, perused and heavily criticised in the book before the two fictional characters start discussing the arrangements of the island of Utopia). To build the argument for More's Utopia incorporating antibodies against dystopian outcomes, it should further be noticed another trait of More's Utopia: its realism. For example, More expounds in detail on how Utopians defend themselves from non-Utopian neighbours: Utopians have engaged with ethical and moral issues and found arrangements that attempt to strike a balance between such contradictions, but leave it open to different solutions. Importantly, Utopia is what a famously entitled book call 'the learning organisation' (Senge, 1990/2006): Utopia is said to have learnt from past encounters, notably with the ancient Egyptians and the ancient Romans, and have updated its institutions as a result of these exchanges.

In sum, utopias are, at least potentially, useful and beneficial if they are realist, dynamic and open to critiques. They are useful if they deal with real problems and outline solutions that are, at least to a significant extent, within the realm of what is possible, or might become possible under relatively realistic conditions (e.g. about certain technological developments). Utopias are also likely to lend themselves to positive usages if they are dynamic: they allow for change over time in responding to problems, rather than prescribing a fixed solution to extant problems. Finally, utopias are useful contrivances if they are open to critiques: More's book ends by commenting on the likes and dislikes of how the island of Utopia works. They are, in sum, sources of learning for imagining new ways forward for the open society (à la Popper), rather than blueprints for the superimposition of allegedly 'best' institutions. The dialogue between the two main characters of the book sways between conflicting poles on many important issues that are continuously brought to the fore, with light touch, irony and humour (in a passage of exquisite irony, the reader is made aware that in Utopia only kids play with that strange, glowing metal which is called gold; adults refrain from such childish play because they devote themselves to the important things in life - work, family, study - and not to the ludicrous activity of pursuing the acquisition of the strange yellow metal - a practice which incidentally also enabled the island of Utopia to accumulate so much gold as to be able to bribe the armies of their enemies before they attack Utopia, and hence over millennia they had almost always entirely avoided war!). And irony and humour, alongside being inherent traits of English character, are surely effective antidotes towards dystopias, which usually tend to treat themselves very seriously.

There is, however, another antidote to utopias turning into dystopias that might be suggested: it is that utopias are better when they are in the plural, 
more than one, offering different perspectives to engage with the big issue of how to improve public governance and administration in worldly contexts. Plurality of utopias is better than having just one utopia. This is the argument put forward by a symposium in Administrative Theory and Praxis (2015, issue 37(2); see Surak, 2015), where 'Polytopian philosophy approach' is the chosen label for arguing in favour of plurality of utopias (see also Stanisevski, 2015): multiple narratives, open narratives, eliciting critical thinking from different angles.

Wrapping up on the story developed throughout this chapter, the masterpieces of three key authors, made centuries ago, provide three perspectives that all bear enduring significance for PA. The 'call to realism', thereby encompassing the gloomiest aspects about human nature and the courses of behaviour we might expect of public officials and citizens alike, made by Machiavelli over five centuries ago is still a powerful reminder to social scientists and food-for-thought nourishing the scientific and critical study of political and public life. The call to get beyond the extant circumstances and contingencies, made by the utopian thinking triggered by More's masterpiece, still pushes scholars and policymakers alike to the continued rediscovery of the reversed perspective that consists in taking the move from the point of destination, rather than the extant circumstances, and then applying a logic of 'backwards mapping' to chart the route that may lead to the betterment of public governance, thus avoiding the pitfalls of getting stuck in path dependency. The image of the effects of public virtues and the good government, set forever in the frescoes of the City Hall of Siena by Lorenzetti, urges whoever is involved in the public service to rediscover the significance of virtues in public life. Together, they furnish a repertoire of conceptual tools from which to tap for the betterment of the study and practice of PA.

\section{NOTES}

1. I am grateful to Elke Löffler and Tony Bovaird for having drawn my attention to this.

2. Drechsler's keynote speech at the IASIA Annual Conference in Paris centred on Lorenzetti's masterpiece and was supported only by visual slides, with no text added to the presentation: the meta-message was indeed that the community of students of public governance and administration does have to rediscover non-verbal knowledge, and non-verbal communication as part and parcel of its methods of inquiry. The text of the speech is available in the e-journal Development in Administration (Drechsler, 2015a).

3. We here follow mainly Drechsler's reading of Il Buon Governo (Drechsler, 2001a, 2015a) and de Graaf for the interpretation of the role of theological virtues for 'good governance'.

4. I am grateful to Wolfgang Drechsler for pointing this aspect of the painting to me. 
5. Although scale may play a role here because Athens' polis was a very small community in terms of size. Notably only a portion of the population enjoyed the status of 'citizens' and most were 'slaves', even after the important constitutional reforms introduced by Solon in the 6th century $\mathrm{BC}$ and Cleisthenes in the early 5 th century BC, which paved the way to the zenith of the 'democratic Athens' that has been admired over the millennia. Siena at the time also encompassed a small population, at least by comparison with modern jurisdictions regulating the lives of millions of people.

6. Although it should be noted most jockeys are not local (I'm grateful to Wolfgang Drechsler for having pointed out this aspect).

7. The ancient age saw a number of authors elaborating on virtue politics (most famously, Cicero's De Republica - 'On the Republic' - a thorough examination of how virtues sustain the prosperity of the political community).

8. However, it should also be noticed that ' $[R]$ esearch on public value is highly contested territory, and prominent scholars have critiqued Moore's early definition on its normative and empirical reasoning; its loose definition of public management; the inability to understand the regulatory activity of states or power relationships between state officials and other agents; primacy afforded to entrepreneurial managers in shaping policies; down-grading of party politics; deference to private sector management models that fail to deal with accountability and democratic politics, and more significantly how limited its utility is in Westminster models of government where there is a sharper distinction between politicians and public servants (Rhodes and Wanna, 2007). Rhodes and Wanna were then challenged for mis-representing Moore's early work on public value, for misunderstanding the complexities of policy making and for drawing on "outdated text book theories of separation of politics and administration" (Alford, 2008)' (Liddle, 2018, p. 969).

9. We refer mainly to Guglielmino and Grosser (1987) for the biographical information on Machiavelli.

10. Critiques of amorality have been addressed to both Guicciardini and Machiavelli, but these may be partly misplaced. We discuss Machiavelli's thought in greater length, here noticing about Guicciardini that he was a fervent promoter of the republic and a democratic form of government. However, through his vicissitudes and changing fortunes, he also matured a disenchanted consciousness of the corrupt nature of human beings - in Judeo-Christian terms: of the fall of mankind - and the likelihood of immoral behaviours and fallacious judgements; he then developed an acute sense of the necessity of proper constitutional arrangements to at least partly offset this state of affairs. For this reason, he opted for also putting his technical expertise to the service of non-republican forms of government, conceiving of the bettering of the functioning of the state as something worth pursuing, even when the configuration of the state did not reflect his preferred constitutional regime.

11. Although this may be a sweetened interpretation of Machiavelli: an alternative interpretation is that his thrust was simply - and ruthlessly - to discover the 'laws of power' to the benefit of the Prince: how the Prince can grab and hang on to power. Whether the ultimate motivation of the pursuit of power is the achievement of lofty ideals or, rather, purely and simply the enjoyment that comes with power and with entering History (in capital) is more conjectural than in Machiavelli's writing.

12. I'm indebted to Geert Bouckaert for this way of conceiving of utopias in PA. 
13. One additional clarification is appropriate. Utopian thinking is not moral law nor foundation of morality; these are two distinct dimensions. Kantian thinking as expressed in The Fundamental Principles of the Metaphysics of Morals (1785) and the Critique of Practical Reason (1788) is not Utopia. The logic of the Kantian categorical imperative lies in urging the rational human being to behave as if categorical imperatives were universal laws of behaviour, and to adhere to such laws even if fully effecting such laws (that is, perfection in moral behaviour) is not attainable in this world. This logic of straining towards perfection in the individual conduct though conscious of its unreachability lies on an altogether different plane than the logic of the iconoclastic usage of utopias for purposes of critique of society and extant governance arrangements (for this reason we disagree with Garofalo and Geuras, 2015, pp. 81-6: whilst integrating moral thinking with utopian thinking may be lofty goal, placing Kantian foundation of morality - the 'kingdom of ends' - under the label of utopia and utopian thinking is misplaced). The misunderstanding may originate in the consideration that both categorical imperatives and utopias have in common the feature of not being realisable in full in this world, but similarities end here. Kantian ideals have a regulatory function that orients practical action towards perfection, they establish the conditions for the possibility of practical human action to be regulated by perfection, and they furnish a measure against which to gauge the distance of actual action: even if ideals do not enjoy the status of real entities as such, they are not chimeras, they are the conditions for practical human action to occur; they are the 'ought to' that constitutes human action as the action of a rational subject. Reason needs a measure of perfection in its own order to judge concrete behaviour and guide it. Regulatory ideals are transcendental, that is they are beyond experience because experience by itself cannot guide what 'ought to' be. Utopias are the outcome of an imaginative process, but they are not an ideal. And they are conceived and crafted on the basis of knowledge acquired through experience (in More's case, 16th-century England). Moreover, categorical imperatives guide individual behaviours; utopias concern the governance of whole socio-political systems.

14. A feature that seems to anticipate Jeremy Bentham's famous Panopticon. 